http://dx.doi.org/10.12775/szhf.2020.005

\author{
Halina ŚWIĘCZKOWSKa \\ UNIWERSYTET W BIAŁYMSTOKU \\ E-MAIL: H.SWIECZKOWSKA@UWB.EDU.PL \\ ORCID: 0000-0002-8702-3760
}

\title{
Leibnizjańska idea języka uniwersalnego
}

Gottfried Wilhelm Leibniz jako filozof języka to w historii filozofii wciąż jeszcze postać rozpoznana jedynie częściowo. Niekiedy można odnieść wrażenie, że jego wkład w badania nad językiem jest albo ignorowany, albo traktowany lekceważąco czy nieżyczliwie ${ }^{1}$. Zadziwiające wydaje się choćby całkowite milczenie o teorii lingwistycznej Leibniza w pracach Noama Chomsky'ego $^{2}$, choć z całą pewnością słuszniejsze byłoby określenie lingwistyki kartezjańskiej mianem leibnizjańskiej. W literaturze światowej od kilkudziesięciu lat można zaobserwować wzmożone zainteresowanie dorobkiem lingwistycznym XVII i XVIII stulecia. Literatura polska dotycząca tego okresu historii filozofii języka przedstawia się dość skromnie, a wiedza o Leibnizu jako teoretyku i filozofie języka stanowi udział niewielkiego kręgu wtajemniczonych. Należy doń niewątpliwie profesor Anna Wierzbicka, która

1 Zob. Pierre Guiraud, La Sémantique (Paris, 1972), 100.

2 Zob. Noam Chomsky, Cartesian Linguistics (New York: Harper \& Row, 1966). Bardzo interesujące rozważania na temat przyczyn nieobecności Leibniza w „lingwistyce kartezjańskiej” prowadzi m.in. Hans Aarsleff w rozprawie „The History of Linguistics and Professor Chomsky", w: Hans Aarsleff, From Locke to Saussure (Minneapolis: University of Minnesota Press, 1982). 
w połowie lat siedemdziesiątych ubiegłego wieku podjęła próbę poszukiwania tradycji współczesnej semantyki, analizując jej leibnizjańskie korzenie ${ }^{3}$.

Leibniz, twórca jednego $\mathrm{z}$ największych nowożytnych systemów filozoficznych, zasługuje na uwagę jako teoretyk języka co najmniej z kilku powodów. Po pierwsze, ze względu na podjęcie przezeń kwestii poznawczej funkcji znaku językowego i jego roli w procesie myślowym. Leibnizjańska teoria poznania zbudowana jest $\mathrm{w}$ znacznej mierze na językowym fundamencie. Po drugie, Leibniz jest przedstawicielem nurtu językoznawstwa materiałowego, autorem wielu studiów i rozpraw, w których podejmuje problematykę pochodzenia języka i klasyfikacji genealogicznej języków świata, prowadzi także badania nad funkcją języka w życiu jednostki i społeczeństwa, podkreślając jego kulturotwórczy charakter ${ }^{4}$. Po trzecie wreszcie, Leibniz jest rozpoznawany najczęściej jako jeden z pomysłodawców idei języka uniwersalnego; idei, która towarzyszyła mu od początku jego drogi naukowej. Pozostawała ona niewątpliwie w ścisłym związku z budowanym przezeń systemem filozoficznym. Można przypuszczać, że kolejne projekty Leibniza zmierzające do jej urzeczywistnienia wynikały również z intensywnych badań nad istniejącymi już systemami językowymi w bardzo szerokim ich rozumieniu. Paradoksalnie jednak, choć identyfikowany z ideą języka doskonałego, Leibniz nie wyszedł nigdy poza wstępne szkice i komentarze dotyczące tego projektu. Warto zatem prześledzić racje uzasadniające potrzebę utworzenia takiego języka i cele, które za jego pomocą chciał osiągnąć.

Esej ten stanowi próbę udzielenia przynajmniej częściowej odpowiedzi na pytanie o motywację Leibniza dotyczącą potrzeby istnienia języka uniwersalnego. Jest ono zasadne między innymi ze względu na stojącą w sprzeczności z ideą języka uniwersalnego wypowiedź Leibniza, w której wyraźnie podkreśla on, że „każdy język, nawet najuboższy, może wyrażać wszystko”,

3 Anna Wierzbicka, „W poszukiwaniu tradycji. Idee semantyczne Leibniza”, Pamiętnik Literacki LXVI (1975): 108-126.

4 Halina Święczkowska, Język jako projekt polityczny (Kraków: Wydawnictwo Aureus, 2008); tejże, Language as the mirror of world order (Białystok: Uniwersytet w Białymstoku, 2016).

5 Gottfried Wilhelm Leibniz, „Analysis linguarum”, w: tenże, Opuscules et Fragments Inédits, extraits des manuscrits de la biblithéque royale de Hanovre par Louis Couturat (Paris, 1903, repr. Hildesheim, 1962), 352, cytowane dalej jako C. 
jak również z uwagi na historyczny wkład filozofa w ideę formalizacji i mechanizacji procesów rozumowań ${ }^{6}$. Prezentowany tekst to również próba rekonstrukcji paradygmatu badań językowych obowiązującego w pewnym obszarze siedemnastowiecznej teorii języka ${ }^{7}$.

\section{Co wcześniej - prawdziwy język czy filozofia?}

W liście do Marina Mersenne’a z 20 listopada 1629 roku$^{8}$ Kartezjusz sformułował uwagi na temat projektu języka uniwersalnego autorstwa niejakiego Hardy’ego, który w rozpowszechnianej w Paryżu ulotce wyłożył w sześciu postulatach swoje poglądy na strukturę takiego języka, a także zadania, jakie miałby spełniać. Kartezjusz nie był zachwycony projektem. Jego uwagi zarówno krytycznie, jak i lekceważąco odnosiły się do przedsięwzięcia. Postulowany język miał być w intencji projektodawcy językiem quasi-naturalnym z uproszczoną regularną gramatyką i słownikiem, w którym każde słowo byłoby prawdziwą definicją rzeczy. Język ten, łatwy do opanowania, stanowiłby punkt odniesienia dla innych języków w tym sensie, że istniejące języki etniczne byłyby jego dialektami. Służyłby też, o wiele skuteczniej, niż to czynią inne języki, przekazywaniu myśli w mowie i piśmie9.

W dużej mierze krytyczna recenzja Kartezjusza zawierała także część pozytywną, w której autor dopuszczał możliwość skonstruowania języka uniwersalnego, choć na innej niż u Hardy’ego zasadzie. Zdaniem Kartezjusza błąd Hardy’ego polegał na przeświadczeniu, że skuteczną metodą upraszczania języka w celu czynienia go łatwiejszym do opanowania jest eliminowanie tych elementów, które nie są konieczne dla jego funkcjonowania. Jednak liczba

6 Zob. Witold Marciszewski, Roman Murawski, Mechanization of Reasoning in a Historical Perspective (Amsterdam-Atlanta: Brill Rodopi, 1995), 103-112.

7 Niniejszy tekst jest rozszerzoną i uaktualnioną wersją VII rozdziału książki Harmonia linguarum. Język i jego funkcje w filozofii Leibniza (Białystok: Uniwersytet w Białymstoku, 1997).

8 René Descartes, Oeuvres de Descartes, t. I, publiées par Ch. Adam, Paul Tannery (Paris, 1974-1983), 76-82, cytowane dalej jako AT.

9 Zob. Jerzy Kopania, Funkcje poznawcze Descartesa teorii idei (Białystok: Dział Wydawnictw Filii UW, 1988), 191 i n. 
elementów struktury językowej nie jest sama przez się przyczyną trudności w opanowaniu danego języka. Nawet bardzo bogaty ilościowo system daje się opanować, jeśli jego elementy są uporządkowane według jakiejś przejrzystej zasady. Kartezjusz wyjaśnia, że:

Chodzi przecież o to, by można było nauczyć się go w bardzo krótkim czasie, a to jest możliwe dzięki porządkowi, to znaczy dzięki ustaleniu porządku między wszystkimi myślami, jakie może pomieścić umysł ludzki, takiego samego jak ten, który w sposób naturalny ustalony jest między liczbami. I tak w jeden dzień można się nauczyć nazywać wszystkie liczby aż do nieskończoności i pisać je w obcym dla siebie języku, a przecież mamy tu do czynienia z nieskończenie wielką ilością różnych słów, tak też można by uczynić z wszelkimi innymi słowami niezbędnymi do wyrażania wszystkiego tego, co napływa do ludzkiego umysłu ${ }^{10}$.

Istotne zatem - zdaniem Kartezjusza - staje się ustalenie samej zasady konstruowania języka uniwersalnego. Ale to ustalenie zależy

od prawdziwej filozofii; bez niej nie jest bowiem możliwe wyliczyć i uporządkować wszystkie myśli ludzkie, a nawet je tylko rozróżnić tak, by stały się jasne i proste, co moim zdaniem jest największą tajemnicą, którą trzeba odkryć, by zdobyć rzetelną wiedzę. I gdyby ktoś poprawnie wyjaśnił, jakie są zawarte w wyobraźni ludzi proste idee, z których składa się wszystko, co ludzie myślą, gdyby ponadto wyjaśnienie to zostało powszechnie uznane, wówczas miałbym nadzieję, że zostanie utworzony uniwersalny język, bardzo łatwy do opanowania zarówno w mowie i piśmie, a co najważniejsze taki, który mógłby wspomagać nasz osąd (Jugement), przedstawiając mu wszystko tak wyraźnie, że prawie niemożliwym byłoby mylić się $e^{11}$.

Leibniz, dysponując kopią tego listu, skomentował wypowiedź Kartezjusza następująco:

Choć język ten zależy od prawdziwej filozofii, nie zależy wcale od jej doskonałości. Można go bowiem ustanowić, nawet jeśli filozofia nie jest jeszcze doskonała, podobnie jak niedoskonała jest nasza wiedza. Tymczasem byłby nadzwyczaj

10 AT I, 80-81, przeł. Jerzy Kopania, 199.

11 AT I, przeł. Jerzy Kopania, 200. 
pomocny w przechowywaniu tego, co wiemy, przeglądaniu naszych niedostatków, odkrywaniu sposobów ich osiągnięcia, a przede wszystkim w rozstrzyganiu wątpliwości, gdy w grę wchodzi poprawność łańcucha rozumowań ${ }^{12}$.

\section{De arte combinatoria}

Nie wiadomo, czy Leibniz znał cytowany wyżej list Kartezjusza, gdy pisał jedną z najważniejszych młodzieńczych prac, Dissertatio de arte combinatoria, ale logiczne i matematyczne wyniki tej rozprawy stworzyły podstawę jego dalszych filozoficznych przedsięwzięć. W De arte combinatoria Leibniz, nawiązując do prac nowożytnych matematyków i filozofów, a także do metody opisywanej w pismach katalońskiego encyklopedysty Raymonda Lullusa, rozwija ideę utworzenia alfabetu ludzkiej myśli. Leibniz wierzył, że wszystkie pojęcia są jedynie kombinacjami prostych, podstawowych pojęć, podobnie jak słowa są nieskończenie zróżnicowanymi kombinacjami liter alfabetu. Ideę tę wyraził następująco: „Rozłóżmy jakikolwiek dany termin na jego składniki formalne, tj. zdefiniujmy go. Następnie rozłóżmy te składniki na ich własne części, czyli dajmy definicje terminów (pierwszej definicji), póki nie dotrzemy do prostych części czy niedefiniowalnych terminów”13. Te proste niedefiniowalne części tworzyłyby alfabet ludzkiej myśli; poprzez ich zestawienie można by więc odkryć wszystkie prawdy, które te połączenia wyrażają.

Punktem wyjścia tej idei był w istocie tradycyjny system definicji przez rodzaj bliższy (genus proximum) i różnicę gatunkową (differentia specifica). Zgodnie z tym podejściem wywodzącym się od Platona i Arystotelesa

12 Gottfried Wilhelm Leibniz, Opuscules et Fragments Inédits, extraits des manuscrits de la biblithèque royale de Hanovre par Louis Couturat (Paris, 1903, repr. Hildesheim, 1962), 28, cytowane dalej jako C.

${ }_{13}$ Gottfried Wilhelm Leibniz, Dissertatio de arte combinatoria in qua ex arithmeticae fundamentis complicationum ac transpositionum doctrina novis praeceptis extruitur, et usus ambarum per universum scientiarum orbem ostenditur; nowa etiam ars meditandi seu logicae inventionis semina spargantur, w: tenże, Die Philosophischen Schriften von G. W. Leibniz, Vol. VII, ed. C. I. Gerhard (1849-1853, repr. Hildesheim, 1960), t. IV, 64-65, cytowane dalej jako GP, tom, strona. 
właściwą metodą definiowania klas rzeczy jest rozpoczęcie od klasy najbardziej ogólnej i podział jej na dwie mniejsze, wzajemnie wykluczające się klasy. Skuteczność tej metody wzmacniało przekonanie, że pojęcie definiowane musi być bardziej złożone niż pojęcie użyte $\mathrm{w}$ definiensie. Zatem, jeśli pojęcie 'człowiek' jest połączeniem pojęć 'zwierzę i i 'rozumne', to składniki te powinny być prostsze niż złożone z nich pojęcie. Pociągało to za sobą przypuszczenie o istnieniu absolutnie prostych atomowych pojęć, gdyż w przeciwnym razie podział ten byłby nieskończony. Analizując ten system definicji pojęć, Leibniz doszedł do przekonania, że proces podziału na gatunki kończy się dopiero w chwili uzyskania całkowitego opisu jakiegoś indywiduum. Znaczy to, że najniższym pojęciem gatunkowym jest pojęcie indywidualne. Wynika stąd, że każdy najniższy gatunek nie może mieć więcej niż jednego podpadającego podeń egzemplarza ${ }^{14}$. W rozprawie De principio individui Leibniz, przyjmując nominalistyczne stanowisko Suareza, iż nie ma i być nie może innych bytów niż jednostkowe, ustalił zasadę identyczności rzeczy nierozróżnialnych, zgodnie z którą nie mogą istnieć dwa identyczne indywidua ${ }^{15}$. Zasada ta odgrywała dużą rolę w poglądach Leibniza. Wiązała się przede wszystkim z pojęciem uniwersalnej harmonii, implikującym systematyczną i harmonijną jedność poszczególnych bytów, z których dowolne dwa różnią się wewnętrznie od siebie, choćby różnica ta była nieuchwytna.

Leibniz, przyjmując istnienie elementarnych pojęć, które stanowiłyby alfabet ludzkiej myśli, założył, że można je zestawiać w nieograniczony sposób. Była to zatem idea zgodna z ideą rachunku. Zilustrował ją przykładem, w którym liczby 3, 6, 7, i 9 przedstawiają cztery proste pojęcia. Tworzą one pierwszą klasę pojęć. Drugą klasę nowych pojęć tworzy się przez kombinację kolejnych par prostych pojęć: $3 \times 6,3 \times 7,3 \times 9,6 \times 7,6 \times 9,7 \times 9$. Podobnie dzięki kombinacji trójek tworzy się trzecią i następne. Jedną z nich jest $3 \times 6 \times 9$, która jest także $1 / 3 \times 9$ lub $2 / 3 \times 6$, gdzie $m / n$ znaczy $m$-termin $n$-tej klasy. Istnieje więc wiele wyrażań tej samej rzeczy, których równoważność weryfikowana jest przez poprzez ich rozkład na czynniki elementarne ${ }^{16}$.

14 Taką interpretację przedstawia George MacDonald Ross w: Leibniz (Oxford: Oxford University Press, 1984), 51-52.

15 Gottfried Wilhelm Leibniz, Gothofiedi Guiliemi Leibnitii Opera Omnia, nunc primum par colleta... par Ludovitius Dudens, vol. VI (Genève, 1767), 11-14.

16 Tenże, De Arte Combinatoria, GP IV, 65. 
Zauważmy, że oprócz zestawu pojęć elementarnych istotne znaczenie mają tu reguły zestawiania tych pojęć. W De arte combinatoria Leibniz przedstawia zarys kombinatoryki, a ustanawiając reguły rachunku numerycznego relacji między obiektami, usiłuje jednocześnie umieścić te relacje w perspektywie daleko wykraczającej poza sam rachunek. Kombinatoryka stanowiła bowiem dla filozofa „metafizyczną doktrynę całości i części”" Leibniz przyjął, że ponieważ

wszystko, co istnieje lub co może być pomyślane, musi składać się z części rzeczywistych lub konceptualnych, cokolwiek różni się naturą, musi koniecznie różnić się tym, że ma inne części, stąd przydatność złożeń; lub przez inną budowę - stąd przydatność rozkładu. Pierwsze są orzekane ze względu na różnorodność materii, drugie $\mathrm{z}$ uwagi na różnicę formy ${ }^{18}$.

Na tej podstawie, jak twierdzi Leibniz, można odkryć nie tylko rodzaje rzeczy, ale także ich atrybuty, cała bowiem twórcza część logiki ugruntowana jest właśnie w złożeniach.

Podobnie jak inni logicy jego czasów, Leibniz odróżniał logikę odkryć i logikę dowodu lub sądzenia. Dotychczas podstawowy sukces logiki polegał na formułowaniu reguł dowodu, takich jak te stosowane w sylogistyce Arystotelesa oraz w aksjomatycznej metodzie geometrii Euklidesa. Zasadniczą trudność stanowił jednak brak niezawodnych reguł pozwalających tworzyć odkrywcze hipotezy.

Leibniz był całkowicie owładnięty wizją logiki odkryć, dostarczającej dowodów dla odkrytych praw. Dodatkowo wzmacniało ją przekonanie, że logika odkryć i dowodu wzajemnie się dopełniają. Ponieważ sądy prawdziwe są zawsze analityczne, symetria sugeruje, że proces odkrywania powinien być syntetyczny lub, używając leibnizjańskiego określenia, kombinatoryczny ${ }^{19}$.

17 Tamże, 36. Zob. Manuel Antonio Correia, „De Arte combinatoria: Unity and Harmony in the Doctrine of the Whole and Parts", w: Leibniz and Europe, VI Internationales Leibniz Kongress Vorträge I Teil (Hannover, 1994), 143-151.

18 Leibniz, De arte combinatoria, GP IV, 44.

19 Leibniz wierzył, że rozumowanie, zarówno analityczne, jak i syntetyczne, może być redukowane do czysto mechanicznych operacji. Co więcej, jego zdaniem wraz z upływem czasu operacje kombinatoryczne staną się analityczne, jeśli wszyscy ludzie zaczną stosować jego metodę zestawień. C, 168. Zob. MacDonald Ross, Leibniz, 61. 
Myśl ta powraca w wielu jego pismach. Przedstawia ją między innymi w rozprawce O powszechnej syntezie i analizie, czyli o sztuce odkrywania i sadzenia ${ }^{20}$. Leibniz wyjaśnia, że proces syntezy rozpoczyna się od zasad prowadzących przez kolejno przebiegane prawdy do odkrywania nowych ciągów, układania z nich tabel i formuł, którymi będzie można się posłużyć w celu znalezienia rozwiązań i problemów, jakie z czasem się wyłonią. Problemem staje się tu w istocie sam dobór pojęć pierwotnych, gdyż ten dokonuje się czysto arbitralnie ${ }^{21}$. Analizując ten problem, Leibniz wskazuje na konieczność posługiwania się kryteriami wyraźności i jasności, zabezpieczającymi jego zdaniem przed przyjęciem pojęć sprzecznych ${ }^{22}$. Sam proces syntezy pojęć nie jest arbitralny, gdyż każde nowo utworzone pojęcie złożone musi być pojęciem możliwym ${ }^{23}$. W omawianej pracy Leibniz ujmuje tzw. alfabet myślenia jako katalog rodzajów najwyższych, z których kombinacji powstawałyby pojęcia niższego rzędu. Pojęcia te, $\mathrm{z}$ natury bardziej szczegółowe, tworzyłyby gatunki niższych rzędów - także te, które są możliwe.

Leibniz traktował kombinatorykę jako naukę o możliwych formach czy strukturach przedmiotowych. W tym rozumieniu była ona nauką ogólną (science generale). Według niego nauka ogólna powinna „dostarczać nie tylko sposobu posługiwania się wiedzą już zdobytą, ale ponadto metody sądzenia i wynajdywania, aby można pójść dalej i uzupełnić to, czego nam brakuje”24. Językiem tej nauki miałby być system znaków jednoznacznie odwzorowujący wszystkie dziedziny przedmiotowe tej nauki - characteristica generalis.

Komentując słowa Kartezjusza, Leibniz był przekonany, że język ten jest niemal w zasięgu ręki. Część pracy miał już za sobą - doskonałą strukturę

20 Gottfried Wilhelm Leibniz, „O powszechnej analizie i syntezie”, w: Mieczysław Gordon, Leibniz (Warszawa: Wiedza Powszechna, 1973), 235.

${ }^{21}$ Pierwotna wartość znaku (charakteru) - ta, która została nadana mu arbitralnie i nie wymaga uzasadnienia - stanowi jego znaczenie (significatio). Fundamenta calculi raticiniatioris, GP, VII, 45; Gottfried Wilhelm Leibniz, „Podstawy formalizacji rozumowań”, w: Gordon, Leibniz, 251.

${ }^{22}$ Gottfried Wilhelm Leibniz, „O powszechnej analizie i syntezie”, w: Gordon, Leibniz, 230. Leibniz wyjaśnia dalej (s. 232), że: „Nie możemy [...] beztrosko budować dowodu na rzecz jakiegoś pojęcia, jeśli nie wiemy, czy jest ono możliwe”.

23 Tamże, 233.

${ }^{24}$ C, 228-229, przeł. Stanisław Cichowicz, w: Gottfried Wilhelm Leibniz, Wyznanie wiary filozofa (Warszawa: Państwowe Wydawnictwo Naukowe, 1969), 469. 
językową; na mocy założenia, że pierwotnymi składnikami rzeczywistości są substancje i ich własności, Leibniz uznał, iż najwłaściwsza, odzwierciedlająca zawieranie się własności w substancji struktura językowa to forma podmiotowo-orzecznikowa. Ponadto miał kombinatorykę, która uogólniona, stanowiła wzorzec nauki ogólnej, oparty na teorii logicznej i matematycznej. Kombinatoryczne podejście wiązało się z wizją niezmienności zbioru wyjściowych pojęć konstytuujących całość ludzkiej wiedzy. Całe poznawcze przedsięwzięcie kombinatoryki polegało na poszukiwaniu zestawień tych pojęć tworzących sądy prawdziwe. Kluczowa dla procedury była dla Leibniza jego Zasada Identyczności. Zgodnie z nią dany sąd jest sądem prawdziwym, jeśli jest sądem identycznościowym lub jest do niego redukowalny. Sąd identycznościowy to taki, w którym predykat jest identyczny z podmiotem lub w tym podmiocie się zawiera, na przykład: $a$ jest a lub ab jest $a$. Można więc powiedzieć, że każdy sąd prawdziwy jest prawdziwy na mocy swojej formy i jako taki jest zdaniem analitycznym. Leibniz dokonał wyraźnego rozróżnienia pomiędzy prawdami rozumowymi a prawdami faktycznymi. Te pierwsze są twierdzeniami koniecznymi w tym sensie, że albo same są twierdzeniami oczywistymi, albo są do nich redukowalne. Wszystkie prawdy rozumowe są z konieczności prawdziwe, a ich prawdziwość opiera się na zasadzie niesprzeczności czy też - co jego zdaniem wychodzi na to samo - na zasadzie tożsamości ${ }^{25}$. Prawdy faktyczne natomiast nie są twierdzeniami koniecznymi, ale są także w jakimś sensie analityczne. Dla Leibniza ,indywidualność ogarnia sobą nieskończoność i ten tylko, kto to zdolny jest pojąć, może poznać zasadę indywidualizacji tej czy innej rzeczy..." ${ }^{26}$. Żaden skończony umysł nie może dokonać tej analizy, zatem „pewność i doskonała racja prawd przygodnych są znane tylko Bogu, który ogarnia nieskończoność jednym aktem intuicji”" ${ }^{27}$. Można więc powiedzieć, że różnica pomiędzy prawdami rozumowymi i faktycznymi odnosiła się u Leibniza zasadniczo do kwestii ograniczoności

25 Zob. Tadeusz Czeżowski, Odczyty filozoficzne (Toruń: Państwowe Wydawnictwo Naukowe, 1969), 154.

${ }^{26}$ Gottfried Wilhelm Leibniz, Nowe rozważania dotyczace rozumu ludzkiego, t. II, przeł. Izydora Dąmbska (Warszawa: Państwowe Wydawnictwo Naukowe, 1955), 32.

27 GP VII, 309. 
ludzkiego poznania ${ }^{28}$. Leibniz dał więc wyraz przekonaniu, że analiza pojęć pierwotnych będzie stanowić podstawę do ogarnięcia całej ludzkiej wiedzy. Można w tym miejscu zadać pytanie o charakter tej listy, a mianowicie: czy wyjściowych pojęć jest nieskończenie czy skończenie wiele? Leibniz, niestety, nie wypowiadał się w tej kwestii precyzyjnie. Zestawienie pojęć pierwotnych z liczbami całkowitymi wskazuje, że jest ich przeliczalnie nieskończenie wiele ${ }^{29}$, ale definicja zbioru tych pojęć jako „alfabetu ludzkiej myśli”30 pozwala zakładać, że Leibniz miał na uwadze pewien zbiór skończony, na mocy faktu, że aktualny umysł dysponuje wiedzą, która zawiera skończoną liczbę elementarnych składników myślenia, choć potencjalnie jest zdolny do rozwijania jej w sposób nieskończony.

Istotny dla usprawnienia czynności poznawczych był leibnizjański postulat inwentaryzacji „całej wiedzy nabytej, lecz rozproszonej i źle uporządkowanej”31, a przynajmniej tej, która wydaje się najważniejsza. Kryterium rozstrzygającym o przynależności zdań do tak określonego zbioru jest przyjmowanie tylko tych, których prawdziwość została dowiedziona, gdyż „prawdziwa wiedza zależy od dowodu" ${ }^{32}$. Problemem w tym miejscu staje się sam dowód, ponieważ wymaga on znajomości prawdziwej metody, która „wzięta w całej rozciągłości” jest zdaniem Leibniza jeszcze „rzeczą całkowicie nieznaną" ${ }^{33}$. Nie ulega jednak wątpliwości, że fundament zbioru zdań składających się na katalog ludzkiej wiedzy stanowią dla Leibniza prawdy logiczne i matematyczne - „jeśli [bowiem] metoda matematyków nie wystarczyła do odkrycia wszystkiego [...], to przynajmniej zdołała uchronić ich od błędów; jeśli zaś nie powiedzieli wszystkiego, co powinni, to nie powiedzieli również wszystkiego, czego nie powinni" 34 .

Dla Leibniza matematyka stanowiła wzorzec dla innych nauk. „Gdyby ci, którzy uprawiali inne nauki, naśladowali matematyków [...], już dawno

${ }_{28}$ Zob. Frederic Copleston, Historia filozofii, t. IV, przeł. Józef Marzęcki (Warszawa: Instytut Wydawniczy PAX, 1995), 279.

29 C, 187.

$30 \mathrm{C}, 430$.

31 C, 229.

32 Gottfried Wilhelm Leibniz, „Przedmowa do nauki ogólnej”, w: tenże, Wyznanie wiary filozofa, 69 .

33 Tamże, 69.

34 Tamże, 69-70. 
mielibyśmy metafizykę pewną, jak również etykę, od której wszystko zależy [...], oprócz tego naukę o ruchach, która stanowi klucz do fizyki, a przeto i do medycyny" ${ }^{35}$. Piękno matematyki polega bowiem na tym, że jako zbudowana $\mathrm{z}$ jednoznacznych symboli nie musi dla przeprowadzania dowodów wychodzić poza swój własny system znakowy i na nich, a nie na rzeczach, przeprowadza swoje operacje. Matematyka opisuje pewne dziedziny przedmiotowe, ale dzięki jednoznaczności odwzorowującego te dziedziny symbolicznego języka w swoich działaniach może ograniczyć się do wybranej symboliki. „Gdyby w innych dziedzinach równie łatwo było wykryć [...] prawdę rozumowań, nie byłoby tak wielu rozbieżnych przekonań" ${ }^{36}$. Wynika stąd, że

gdyby dało się wynaleźć znaki graficzne lub umowne (caracterès ou signes), nadające się do wyrażania naszych myśli równie jasno i ściśle, jak arytmetyka wyraża liczby lub analiza geometryczna linie, to można byłoby w każdej dziedzinie - o ile tylko podlega ona rozumowaniu - zrobić wszystko, co można zrobić $\mathrm{w}$ arytmetyce lub geometrii ${ }^{37}$.

\section{Próby konstrukcyjne}

Inspirowany symboliką matematyczną Leibniz podjął wstępne prace nad ustaleniem zestawu pojęć wyjściowych i odpowiedniej dla nich notacji. Eksperymentował $\mathrm{z}$ wieloma systemami. W jednym z projektów zaproponował użycie liczb pierwszych na oznaczenie pojęć pierwotnych. Ich iloczyny tworzyłyby pojęcia złożone. Tak więc, jeśli zwierzę $=2$, rozumne $=3$, to człowiek $=6=2 \times 3^{38}$. Język ten nie satysfakcjonował jednak Leibniza. Nie spełniał on jednego z podstawowych wymagań; struktura symboli powinna odpowiadać bowiem strukturze znaczeń, ale bardzo duże liczby nie ujawniają w sposób oczywisty swoich składników, trudno więc ukazać w zrozumiały sposób zawieranie się orzeczeń w podmiocie, co jest możliwe w przypadku

35 Tamże, 70.

${ }^{36}$ Leibniz, „Przedmowa do nauki ogólnej”, 72.

37 Tamże.

38 Zob. Louis Couturat, La Logique de Leibniz (Paris: Hachette, 1901), 62 oraz GP VII, 78, przypis 1 . 
krótszych zestawień. Nie jest też zupełnie jasne, według jakich kryteriów Leibniz dokonywał wyboru pojęć pierwotnych. Trudno je także rozpoznać w projekcie z $1678^{39}$ roku. Sam Leibniz, świadomy praktycznych trudności $\mathrm{w}$ wytłumaczeniu jego potencjalnym użytkownikom potrzeby stosowania języka uniwersalnego, chciał ich przekonać systemem, który spełniałby wymagania elegancji i prostoty. Zaproponował więc zastosowanie spółgłosek, które odpowiadałyby dziewięciu cyfrom w następujący sposób:

$\begin{array}{lllllllll}1 & 2 & 3 & 4 & 5 & 6 & 7 & 8 & 9 \\ \text { B } & \text { C } & \text { D } & \text { F } & \text { G } & \text { H } & \text { L } & \text { M } & \text { N }\end{array}$

oraz użycie samogłosek, które wyrażałoby miejsce dziesiętne cyfry:

$\begin{array}{ccccc}1 & 10 & 100 & 1000 & 10000 \\ \mathrm{~A} & \mathrm{E} & \mathrm{I} & \mathrm{O} & \mathrm{U}\end{array}$

Dyftongi mogłyby być stosowane dla wyrażenia wyższych potęg 10 . Tak więc na przykład liczbę 81374 oznaczałoby mubodilefa. Niezwykłość i piękno tego pomysłu polegało zdaniem Leibniza na tym, że ta sama liczba może być wyrażona także słowem bodifalemu, gdzie miejsce dziesiętne cyfry wskazują samogłoski lub famuledibo czy lebomufadi. W rzeczywistości istnieje 120 permutacji tego pięciosylabowego słowa. Ten zawrotny wybór pełnych synonimów stwarza ogromne możliwości wyrażania. Pozwala tworzyć najbardziej subtelne poematy $\mathrm{z}$ zachowaniem tego samego znaczenia, co zdaniem Leibniza jest jedną z największych zalet tego systemu ${ }^{40}$.

Kierując się kryterium estetycznym, Leibniz rozważał także możliwość zastosowania zapisu muzycznego ${ }^{41}$. O tym, że projekt nigdy nie doczekał się realizacji, świadczy uwaga autora zawarta w Nowych rozważaniach...: „można by mówić, tzn. dawać się słyszeć, za pomocą dźwięków artykułowanych, gdyby się posługiwano tonami muzycznymi, ale większą byłoby sztuką wynaleźć mowę tonów..." ${ }^{42}$.

\footnotetext{
39 C, 277-278.

40 Tamże, zob. też Couturat, La Logique de Leibniz, 62-63.

41 C, 280.

${ }^{42}$ Leibniz, Nowe rozważania dotyczące rozumu ludzkiego, t. II, 8.
} 
Choć większość eksperymentów Leibniza wydaje się fragmentaryczna i zupełnie nieprzystająca do ideologii całego przedsięwzięcia, którego celem był doskonały język uniwersalny, to na uwagę zasługuje system przedstawiony w Generales inquisitiones de Analysi Notionum et Veritatum ${ }^{43}$, który jest algebraicznym ujęciem relacji między pojęciami. System ten, nazwany przez Leibniza rachunkiem pojęć (calculus ratiotinator, calculus universalis), to formalny, dedukcyjny systemem konstytuujący część nauki ogólnej (scientia universalis). Leibniz zauważył, że logika dotyczy w istocie klas rzeczy lub pojęć. Różnica między podmiotem a orzecznikiem, jakkolwiek ważna z gramatycznego punktu widzenia, nie ma większego znaczenia w logice. Podmiot może bowiem równie dobrze wystąpić jako orzecznik i vice versa; np. zamiast Każdy człowiek jest rozumny można powiedzieć, że Rozumność jest konstytutywna cecha człowieczeństwa. Prowadzi to jednak, jak zauważył Leibniz, do zasadniczych różnic w sposobie ujęcia relacji pomiędzy podmiotem i orzecznikiem, w zależności od tego, czy są one rozważane jako denotujące klasy, czy też jako pojęcia. Jeśli weźmiemy pod uwagę schemat zdania ogólnego Każde $S$ jest $P$, to interpretowany intensjonalnie (czyli pojęciowo) znaczy, że pojęcie $S$ zawiera w sobie pojęcie $P$. Rozważany natomiast ekstensjonalnie (czyli zakresowo) znaczy, że klasa $S$ jest podklasą klasy $P$. Wybierając interpretację intensjonalną, Leibniz kierował się pewnymi założeniami filozoficznymi, utrzymywał bowiem, że podmioty zdań są w istocie wysoce złożonymi predykatami zawierającymi w sobie wszystkie możliwe orzeczniki, które da się o podmiocie wypowiedzieć. Nie będziemy tu wchodzić w szczegóły techniczne systemu wyłożonego w Generales inquisitiones, warto jednak zwrócić uwagę na konsekwentne stosowanie przez Leibniza zmiennych w sposób pozwalający odnosić je do obiektów dowolnego rodzaju, a przede wszystkim na algebraiczne ujęcie zależności pomiędzy zdaniami ogólnymi i ich przekładem na zdania egzystencjalne. Wprowadzając zwroty: est ens (istnieje) i non est ens (nie istnieje) używał ich Leibniz w znaczeniu, które - jak twierdzi

43 C, 356-399, zob. także Gottfried Wilhelm Leibniz, Allgemeine Untersuchungen über die Analyse der Begriffe und Wahrheiten (Hamburg: Felix Meiner Verlag, 1982) i zawarty tam komentarz oraz bibliografia. 
wielu badaczy - antycypuje system algebry Boole’a - est ens równoważne jest bowiem $\mathrm{z} \neq 0$, non est ens można rozumieć jako $=0^{44}$.

\section{Przebudowa języka łacińskiego}

Być może brak wyraźnego postępu w pracach nad stworzeniem od podstaw języka, który byłby twórczym narzędziem rozwijania ludzkiej wiedzy, spełniającym ponadto kryteria estetyczne, sprawił, że Leibniz zdecydował się zaatakować problem z innej strony, zwracając swoją uwagę na łacinę - międzynarodowy język nauki. Wierzył, że reforma istniejącego języka pozwoli na oczyszczenie go z właściwych wszystkim językom zjawisk prowadzących do błędów w słownym formułowaniu myśli: amfibolii, ekwiwokacji etc., a także pozwoli wyeliminować wszystkie nieregularności. Pierwszym krokiem takiej reformy byłoby uproszczenie całej gramatyki. Leibniz odwołał się tu do pewnych wzorców, których dostarczył stworzony na bazie włoskiego język stosowany w handlu śródziemnomorskim - lingua franca, a także uproszczony język przedstawiony przez włoskiego jezuitę Philippa Labbé w pracy Grammatica linguae universalis z 1663 roku. W Nowych rozważaniach... filozof wspomniał także o uproszczonym systemie języka łacińskiego pewnego dominikanina, którego spotkał podczas swojego pobytu w Paryżu ${ }^{45}$. Niewątpliwie argumentem na rzecz redukcji systemu gramatycznego była łatwość jego opanowania, ale wydaje się, że motywy, którymi kierował się Leibniz, miały głębsze podłoże filozoficzne. Jeśli bowiem świat rzeczywisty składa się $\mathrm{z}$ akcydensów, to może być opisany przez zbiór zdań o postaci: $A$ est $B$, gdzie $A$ to kompletne indywidualne pojęcie danej substancji, $B$ zaś - jej akcydens. Wobec tego wszystkie sądy, które mają inną postać, powinny być redukowalne do tego schematu.

Uproszczenie gramatyki miało polegać na całkowitej rezygnacji z fleksji. Modelem były tu dla Leibniza tzw. języki analityczne, czyli te, w których

44 Zob. Marciszewski, Murawski, Mechanization of Reasoning in a Historical Perspective, 81-82.

${ }^{45}$ Leibniz, Nowe rozważania dotyczace rozumu ludzkiego, t. II, 15-16. 
wszystkie wyrazy są nieodmienne ${ }^{46}$. Filozof dowodził, że fleksja jest redundantna w języku, który posiada partykuły, takie jak przyimki, spójniki i zaimki $^{47}$, na przykład „przypadki odpowiadają przyimkom, a często przyimek zawarty jest w nazwie i przez nią pochłonięty"48.

Reformie powinna także ulec liczba części mowy ${ }^{49}$. Leibniz postulował między innymi redukcję rzeczowników do przymiotników określających byt czy rzecz (Ens lub Res): Idem est homo quod ens humanum; przysłówki do przymiotników (imiesłowów lub rzeczowników odczasownikowych - zamiast valde potio, sum magnus potator) oraz wszystkie czasowniki do czasownika est ${ }^{50}$. W wyniku tej redukcji otrzymujemy słownik składający się z jednego rzeczownika oznaczającego rzecz, jednego czasownika oraz listy przymiotników. Do tego zestawu wyrażeń dołącza Leibniz także partykuły. Dzięki tej klasie wyrażeń, zwłaszcza po odrzuceniu fleksji, zyskujemy możliwość łączenia wyrażeń w złożone całości. Partykuły bowiem wiążą nie tylko części przemówienia składającego się ze zdań i części zdania złożonego z idei, ale nadto i części idei powstałej na różne sposoby przez zestawienie ze sobą innych idei. Wprawdzie partykuły należą do słownika, ale reguły ich stosowania wyznaczają gramatykę tak uproszczonego języka. Leibniz pisze zresztą wprost, że słowa należą do słownika, partykuły zaś do gramatyki (Voces pertinet ad Dictionarium, particulae ad Grammaticam $)^{51}$. Reformę gramatyki uzasadnia następująco:

46 Analityczność języków jest sprawą stopnia; typowymi językami izolującymi są wietnamski i chiński. Zob. John Lyons, Wstęp do językoznawstwa, przeł. Krzysztof Bogacki (Warszawa: Państwowe Wydawnictwo Naukowe, 1975), 212. Leibniz żywo interesował się językiem chińskim, dlatego może dziwić, że zamiast zająć się tym językiem, poszedł w kierunku reformowania łaciny. O szczególnym stosunku Leibniza do języka chińskiego i planach z nim związanych piszę nieco dalej.

47 Couturat, La Logique de Leibniz, 67-68. Zob. także D. P. Walker, „Leibniz and Language", Journal of the Warburg and Courtauld Institutes 35 (1972): 298.

48 Leibniz, Nowe rozważania dotyczace rozumu ludzkiego, t. II, 101.

49 Couturat, La Logique de Leibniz, 67-68.

50 C, 281. Zob. tenże, La Logique de Leibniz, 70.

51 Marcelo Dascal, „Leibniz on Particle”, w: Leibniz, Humboldt, and the Origins of Comparativism, red. Tulio de Mauro, Lia Formigari (Amsterdam-Philadelphia: John Benjamins Publishing, 1990), 56. 
Rozróżnienie rodzaju nie jest istotne dla gramatyki filozoficznej ani też rozróżnienie pomiędzy deklinacją i koniugacją nie ma żadnego zastosowania w tej gramatyce. Tak więc odróżniamy rodzaje, deklinacje i koniugacje bez żadnego pożytku, bez korzyści dla zwięzłości - może jedynie to zróżnicowanie jest przyjemne dla ucha; ale te rozważania nie dotyczą filozofii, zwłaszcza że chcemy dodać piękna językowi racjonalnemu inną metodą, tak że nie będzie konieczne zastanawianie się nad bezużytecznymi regułami ${ }^{52}$.

Na mocy założenia, że vocabula sunt voces aut particulae, słowa konstytuują rzecz, partykuły zaś formę dyskursu ${ }^{53}$, zasadniczą kwestią staje się analiza i klasyfikacja załączonych do tej klasy wyrażeń. Leibniz wielokrotnie podkreślał poznawczy charakter tego przedsięwzięcia. Jeśli we wcześniejszych pracach traktował partykuły jako formę dyskursu, to w Nowych rozważaniach... stają się one formami samego myślenia ${ }^{54}$. Marcello Dascal w szkicu Leibniz on Particles $^{55}$ rekonstruuje jego program badawczy, wskazując między innymi, że dla Leibniza najważniejsza jest zasada oszczędności, która oznacza redukcję wielości, nieporządku i złożoności do zbędności, regularności i prostoty. Wynika z niej bezpośrednio dyrektywa poszukiwania regularnych znaczeń oraz potrzeba konstruowania takich definicji partykuł, które ujawniłyby ich wzajemną zastępowalnośćs6.

Leibniz odrzucił tradycyjne morfologiczne kryterium niedeklinowalności, które stosowali gramatycy, wyraźnie kierując się kryteriami funkcjonalnymi. Partykułami były dla niego te wyrażenia, które pełniły wszelką funkcję pomocniczą. Nie wyjaśnił jednak bliżej, jak rozumieć naturę owej funkcji, co czyniło klasę partykuł wielce niejednorodną. Na przykład do klasy tej

${ }^{52}$ Cytat w tłumaczeniu własnym podaję za: Robert McRae, „Locke and Leibniz on Linguistic Particles”, Synthese 75, 2 (1988): 13. Cytat nie pokrywa się z danymi bibliograficznymi wskazanymi przez autora.

53 C, 288.

54 Leibniz, Nowe rozważania dotyczące rozumu ludzkiego, t. II, 105.

55 Dascal, Leibniz on Particles, 35.

${ }^{56}$ Leibniz tłumaczy, że „aby dobrze wyjaśnić partykuły, nie wystarczy abstrakcyjne ich tłumaczenie [...], lecz trzeba się uciec do omówienia, które by mogło je zastąpić, jak definicja może zastąpić miejsce tego, co definiowane. Kiedy się będzie dbało o wyszukiwanie i ustalenie tych możliwych do podstawienia omówień dla wszystkich partykuł, o ile tylko są temu dostępne, wówczas unormuje się ich znaczenia”. Leibniz, Nowe rozważania dotyczące rozumu ludzkiego, t. II, 103. 
włączone były, jako pomocnicze, zaimki quis i ille, czasowniki sum i habeo, przysłówki quomodo i sic oraz oczywiście przedimki i spójniki $\mathrm{i}^{57}$.

Zwróćmy jednak uwagę, że choć kryterium pełnienia funkcji pomocniczej nie odbiega zasadniczo od średniowiecznego podziału na wyrażenia kategorematyczne i synkategorematyczne, to Leibniz modyfikuje zakres tej ostatniej klasy wyrażeń, włączając do niej te, które gramatyka spekulatywna traktowała jako samodzielne znaczeniowo i niezbędne do utworzenia zdania. Kryterium wskazane przez Leibniza nie rozstrzyga, czy wyrażenie jest pozbawione znaczenia. Co więcej, postulat analizy regularnych znaczeń implikuje, że partykuły pełnią pewne funkcje znaczeniowe. Leibnizjańskie kryterium niesamodzielności bliskie jest podziałowi wyrażeń na kategorie podstawowe i kategorie wyrażeń niesamodzielnych, przyjętemu we współczesnej semiotyce logicznej. Można dostrzec tu pewną analogię między wskazaną przez Leibniza klasą partykuł a klasą wyrażeń funktorowych. Wyraźnie zwraca on bowiem uwagę na różnice pomiędzy przyimkami, które łączą nazwy, a spójnikami, które łączą zdania. „Praepositiones jungunt nomina, conjunctiones jungunt integras propositiones" ${ }^{58}$. Według Leibniza jedyną klasę wyrażeń, które są znakami pojęć, stanowią nazwy; reszta to sposoby ujęcia rzeczy (to semantyczne kryterium przedstawia Leibniz w Characteristica verbalis) ${ }^{59}$, a podstawą wszelkich czynności poznawczych jest sąd podmiotowo-orzecznikowy. Mamy tu zatem do czynienia z propozycją znacznego uproszczenia systemu językowego, połączoną z próbą uzgodnienia kategorii znaczeniowych z kategoriami gramatycznymi.

Pojawia się jednak pewna niekonsekwencja. Otóż analizując naturę partykuł, Leibniz pisze, że w języku filozoficznym partykuły, afiksy i końcówki nie są wyszczególnione, a zatem każda część słowa będzie słowem ${ }^{60}$. Uwaga ta jest zaskakująca, gdyż przyjmując jako model wyjściowy języki analityczne, Le-

57 Dascal, Leibniz on Particles, 39. Dascal analizuje leibnizjański system partykuł, odwołując się do tekstów Leibniza opublikowanych w zbiorze Vorausedition zur Reihe VI - Philosophische Schriften. Manuskriptdruck, Leibniz-Forsungstelle der Universität Münster (Münster, 1982). Nie mając, niestety, dostępu do tej pracy, referuję ten system na podstawie opracowania Dascala, które jest najpełniejszym znanym mi ujęciem studiów Leibniza nad partykułami.

58 Zob. tenże, Leibniz on Particles, 54, przypis 30.

59 C, 434.

$60 \mathrm{C}, 433$. 
ibniz założył jednocześnie, że projekt przebudowy języka łacińskiego będzie polegać, przynajmniej w fazie wstępnej, na usunięciu redundantnej wobec partykuł fleksji. Można przypuszczać, że Leibniz, kierując się zasadą oszczędności, kolejnym etapem redukcji uczynił cały zestaw wyrażeń pomocniczych, dążąc tym samym do zastąpienia ich wszystkich konstrukcjami, które sprowadzałyby się do formy podmiotowo-orzecznikowej, na przykład:

Titius est magis doctus Caio równoważne jest, według Leibniza, ze zdaniem: Quatenus Titius est doctus, et Caiues est doctus, eatenus Titius est superior et Caius est inferior, a zatem Titius est doctus, et qua talis est supeitor, quatenus inferior qua doctus est Caius ${ }^{61}$.

Petrus scribit pulchrè: Petrus scribit aliquid pulchrum < seu Petrus scribit (lub Petrus est scribens), et quod Petrus scribit est pulchrum ${ }^{62}$.

Paris est amator Helenae: Paris amat (et eo ipso) Helena amatur ${ }^{63}$.

Homines scribunt: Titius est scribens, Caius est scribens. Titius est homo. Caius est $\mathrm{Homo}^{64}$.

Termin redukcja był rozumiany przez Leibniza bardzo szeroko. Czasem odnosił się do redukcji trybów jednego sylogizmu do drugiego czy też redukcji jakiegoś problemu do innych. Proces ten dotyczył także zdań. Poza wskazanymi wyżej próbami Leibniz podaje wiele przykładów takich przekształceń. I tak:

Oetrus est similis Paulo. Ergo Paulus est similis Petro redukuje się do zdań: Petrus est A nunc et Paulus est A nunc ${ }^{65}$.

Nullus homo est lapis: Omnes Homines non sunt lapides ${ }^{66}$.

Celem tych analiz było przede wszystkim zachowanie logicznej równoważności zdań poddanych redukcji z ich odpowiednikami. Trudno natomiast o spełnienie tego wymogu $\mathrm{w}$ innych przypadkach, dyskusyjna jest choćby równoważność zdania Homines scribunt ze wskazaną przez Leibniza

$\begin{array}{ll}{ }^{61} & \text { C, } 280 . \\ { }^{62} & \text { C, } 244 . \\ { }^{63} & \text { C, } 287 . \\ { }^{64} & \text { C, } 244 . \\ { }^{6} & \text { Tamże. } \\ { }_{6} & \text { C, 323. }\end{array}$ 
koniunkcją zdań jednostkowych, z uwagi na jej eliptyczny charakter. Można bowiem interpretować je jako zdanie ogólne: Omnes homines scribunt, zdanie egzystencjalne: Quidam homines scribunt, lub zdanie, w którym nazwa homines występuje jako nazwa gatunku. Wydaje się jednak, że choć tzw. analiza redukcyjna była dla Leibniza jednym ze środków prowadzących do utworzenia gramatyki języka uniwersalnego, to w równym stopniu służyła jako metoda poszukiwania regularności struktur językowych w istniejących językach etnicznych. Ta regularność, zwana przez Leibniza także uniwersalnością lub racjonalnością ${ }^{67}$, obejmuje wszystko, co jest $\mathrm{w}$ języku ogólne ${ }^{68}$. W tym znaczeniu analiza redukcyjna nie zawsze prowadzi do przekształceń, które spełniają kryteria równoważności logicznej, pozwala natomiast dostrzec ogólny charakter pewnych form językowych i jako taka przygotowuje grunt do poszukiwań uniwersalnych struktur logicznych ${ }^{69}$.

Warto wspomnieć tu o innych źródłach inspiracji Leibniza. Niezależnie od samodzielnych prób konstrukcyjnych pozostawał on pod pewnym wpływem tradycji hermetycznej, studiował pisma alchemików, pitagorejską numerologię i kabalistykę ${ }^{70}$. Nie krył fascynacji ideogramami i kryptogramami, prowadził intensywne studia nad językiem chińskim i miał nadzieję na odkrycie klucza, który umożliwiłby rozpoznanie prawdziwego, naturalnego związku między znakami i pojęciami. W jednym z listów do ojca Bouvet, misjonarza jezuickiego w Chinach, dostarczającego Leibnizowi materiału do badań, pisał, że nowy język, który planuje jako cudowny rachunek umysłu, będzie kontynuacją systemu znaków zawartego w księdze I - Ching, przypisywanej legendarnemu cesarzowi Fohi. Będzie to także szczególny język najwyższej kasty, najbardziej oświeconych intelektualistów ${ }^{71}$.

${ }^{67} \mathrm{C}, 35$.

68 C, 353.

69 Zob. Dascal, Leibniz on Particles, 49 oraz Benson Mates, The philosophy of Leibniz (Oxford: Oxford University Press, 1986), 178-183.

${ }^{70}$ GP VII, 184.

${ }_{71}$ Zob. Franz Rudolf Merkel, „Leibniz und China”, w: Leibniz zu seinem 300. Geburtstag (Berlin: W. De Gruyter, 1952), 55. 


\section{Idea języka uniwersalnego w XVII wieku}

Jeśli analizujemy leibnizjańską ideę języka uniwersalnego, musimy pamiętać, że idea ta wyrosła na pewnym gruncie cywilizacyjnym i kulturowym Europy XVII wieku. Odkrycia geograficzne, rozwój ekonomiczny pociągający za sobą ożywioną wymianę handlową, potrzebę komunikacji językowej pomiędzy Europą i resztą świata, a także rozwój języków narodowych to tylko niektóre przyczyny, które przesądziły o zaangażowaniu badaczy w prace nad skonstruowaniem języka, który sprostałby zarówno potrzebom życia codziennego - jako międzynarodowy system komunikacji - jak i spełniałby wymagania stawiane językowi nauki. Leibniz konkurował na tym polu $\mathrm{z}$ wieloma innymi uczonymi i trzeba wyraźnie powiedzieć, że przypisywanie mu prekursorstwa czy też wyjątkowej roli w tej dziedzinie jest jeśli nie bezpodstawne, to co najmniej dyskusyjne.

Wiek XVII można - bez popadania w nadmierną przesadę - nazwać epoką projektów języka uniwersalnego ${ }^{72}$. Poszukiwania i próby konstrukcyjne podążały w różnych kierunkach: jedne w celu wskazania systemu najdoskonalszego skupiały się na badaniach i porównywaniu języków istniejących, inne były projektami uproszczenia wybranych języków etnicznych, jeszcze inne zaś ambitnymi planami budowy języka od podstaw. Leibniz wypróbował każdy z tych sposobów. Studia porównawcze nad językami etnicznymi doprowadziły go do wniosku, że u ich źródeł leżał jakiś język pierwotny o własnościach spełniających być może wymogi języka uniwersalnego, język zwany przez niektórych Adamowym, którego rekonstrukcja jest niemożliwa. Trudno tu jednak o całkowitą konsekwencję, czasami bowiem twierdził, że język ten odzwierciedlał jedynie stan zaawansowania poznawczego pierwotnych społeczeństw, a czasami głosił, że barbarzyńcy mieli więcej instynktu niż rozumu. W dyskusji nad prymatem historycznym i kulturowym języków dał się ponieść emocjom, twierdząc, że najbliższy Adamowemu jest język niemiecki i ten właśnie spełnia kryteria języka filozoficznego. Tak radykalne stanowisko w tej kwestii uległo osłabieniu pod wpływem zetknięcia

${ }^{72}$ Historię różnych projektów języka uniwersalnego obszernie wykłada Marian Jurkowski w książce Od wieży Babel do języka kosmitów (Białystok: Krajowa Agencja Wydawnicza, 1986). 
się filozofa z cywilizacją Dalekiego Wschodu. Leibniz zaczął przypuszczać, że język chiński kryje całą prawdę o rzeczach ${ }^{73}$. Nie był tu zresztą odosobniony, podobną opinię wyraził znacznie wcześniej Francis Bacon, który twierdził, że ideogramy tego języka są to „characters real, which express neither letters nor words in gross, but Things or Notions"74.

Bacon jako jeden z pierwszych rozważał projekt stworzenia języka uniwersalnego, który byłby systemem ideograficznym. Pisał o tym w The Advancement of Learning (1605), a także w późniejszej rozprawie De Augmentis Scientiarum (1623). Choć Bacon dostrzegał pewne korzyści z urzeczywistnienia swego pomysłu - ,any book written in characters of this kind can be read off by each nation in their own language", to trudnością samą w sobie byłoby opanowanie takiego języka, gdyż zawierałby on „a vast multitude of characters; as many, I suppose, as radical words"75. Sama idea Bacona była jednak na tyle nośna, że pojawiały się liczne próby jej realizacji. Można tu wymienić wspólny projekt Williama Bedella, biskupa Kilmore i Wielebnego Jonstona z 1633 roku, projekt Hermana Hugo, Philipa Labbé i Edwarda Somerseta. W 1657 roku Cave Beck opublikował w Ipswich gramatykę i słownik takiego języka pt. The Universal Character. Podobne prace wydane zostały przez J. J. Bechera we Frankfurcie w 1661 roku (Character, pro notitia linguarum universali) i Athanasiusa Kirchera w Rzymie w 1663 roku (Polygraphia Nova et Universalis) ${ }^{76}$.

Trudności wskazywane przez Bacona zdawał się przezwyciężać program nakreślony przez Kartezjusza we wspomnianym już wcześniej liście do Mersenne’a. Kartezjusz, choć przekonany o teoretycznej możliwości skonstruowania języka uniwersalnego, którego struktura odwzorowywałaby struktury myślenia, nigdy nie podjął próby jego realizacji, uznając, że wpierw trzeba odkryć „prawdziwą filozofię”. Co więcej, mimo dostrzeżenia wartości poznawczej takiego języka wyraził zasadniczy sceptycyzm co do możliwości praktycznych ${ }^{77}$. Program kartezjański stał się wyzwaniem dla innych badaczy

${ }^{73} \mathrm{C}, 35$.

${ }^{74}$ Francis Bacon, „The Advancement of Learning”, w: Philosophical Works, red. John M. Robertson (London: George Routledge and Sons, 1905), 121.

75 Francis Bacon, „De Augumentis Scientiarum”, w: Philosophical Works, 522.

76 Zob. John Cohen, „On the Project of a Universal Character”, Mind LXII (1954): 54.

77 AT I, 81-82. Zob. Kopania, Funkcje poznawcze Descartesa teorii idei, 201. 
i jako jeden z pierwszych podjął go Mersenne, który o swoim projekcie wspomina w liście z 1636 lub 1637 roku $^{78}$. Do idei kartezjańskiej nawiązuje również projekt Francisa Lodowycka przedstawiony w książce z 1647 roku pt. A Common Writing, whereby two, although not understanding on the others language yet by the help thereof may communicate their minds one to another i udoskonalony w pracy z 1652 roku pt. The Groundwork, or foundation laid (or so intended) for the framing of a new perfect language and an universal or common writing. Uniwersalny język Lodowycka był systemem ideograficznym. Jedyny zaś projekt oparty na fonogramach to system przedstawiony przez sir Thomasa Urquharta w 1651 roku $^{79}$.

Na szczególną uwagę zasługuje idea języka uniwersalnego Setha Warda z 1654 roku. W pracy Vindiciae Academiarum pisał:

ponieważ wszystkie rozprawy ustanawiane są w zdaniach, a te w słowach, słowa zaś oznaczają proste pojęcia lub są do nich sprowadzalne, wskazuje to, że jeżeli wykryje się wszystkie rodzaje prostych pojęć i przyporządkuje się im symbole, których w porównaniu z innymi będzie wyjątkowo niewiele, a zatem zasady ich złożeń będą łatwo rozpoznawalne, to najbardziej nawet złożone całostki będą natychmiast zrozumiałe i jeszcze będą przedstawiać bezpośrednio $\mathrm{w}$ widzialny sposób wszystkie elementy złożenia $\mathrm{i}$ jako takie prowadzić będą w naturę rzeczy ${ }^{80}$.

Wprawdzie pomysł Warda nie doczekał się realizacji, ale przedstawiona przezeń idea mieści się w ramach kartezjańskiego modelu języka, a co więcej - jest wyjątkowo zbieżna z późniejszymi projektami Leibniza, który wprawdzie nie powoływał się na ustalenia brytyjskiego uczonego, znał jednak inne angielskie projekty - opublikowaną w 1661 roku pracę George’a Dalgarno pt. Ars Signorum, vulgo Character Universalis et Lingua Philosophica oraz Essay towards a Real Character and a Philosophical Language (1668) autorstwa Johna Wilkinsa. Zdaniem Leibniza jednak ani Dalgarno, ani Wilkins nie uchwycili wystarczająco doniosłości rzeczy i ich języki osiągnęły tylko jedno - są użyteczne jako narzędzie komunikacji. Ponadto twierdził: „prawdziwa Characteristica realis, jaką sobie wyobrażam, powinna być zaliczona

\footnotetext{
78 AT I, 572.

79 Zob. Cohen, On the Projects of a Universal Character, 55.

80 S. Ward, Vindiciae Academiarum (Oxford, 1654), 21.
} 
pomiędzy najprzydatniejsze narzędzia ludzkiego umysłu, jako naturalnie posiadająca nieprzezwyciężoną siłę i do odkrywania, i do zachowywania, i do sądzenia" ${ }^{81}$. Trzeba wszak dodać, że projekty Dalgarno i Wilkinsa, chociaż nigdy nie stosowano ich w praktyce, były pełnymi systemami językowymi, tymczasem plany Leibniza pozostały jedynie w sferze marzeń.

\section{Magiczny urok algorytmu}

Wprawdzie $\mathrm{w}$ poszukiwaniach doskonałego systemu reprezentacji myśli Leibniz miał licznych poprzedników, to jednak istnieje coś, co rozstrzyga o wyjątkowym charakterze leibnizjańskiej idei języka uniwersalnego. Kartezjusz, choć wskazał kierunek poszukiwań, to kwestionując użyteczność poznawczą jakiegokolwiek systemu językowego, odrzucił potrzebę ustanowienia języka uniwersalnego. Rozumiejąc znak w sposób czysto konwencjonalistyczny, głosił, że strona materialna znaku nie ma żadnego związku ze znaczeniem, co przeczyło użyteczności wyrażeń języka w operacjach myślowych. Oznaczało to, że myślenie jako operacja na ideach nie może być wsparte niczym materialnym. Kartezjańska metodologia odwoływała się zatem do bezpośredniego kontaktu umysłu z przedmiotem poznania. Zgodnie z nią bowiem umysł ujmuje rzecz nie poprzez słowo, które może się do niej odnieść, lecz poprzez jej ideę, jaką ma zawsze w sobie, a którą w danym momencie uświadamia ${ }^{82}$. Metodologia leibnizjańska wskazywała na nieodzowny charakter innego sposobu myślenia, w którym kontakt umysłu z obiektem poznania nie jest bezpośredni, ale odbywa się za pomocą znaków jako tych narzędzi myślenia, które przedstawiają przypisany im obiekt. Znaki powinny

${ }^{81}$ GP VII, 7: „[...] sed vera Characterstica realis, qualis a me concipitur, inter aptissima humanae Mentis instrumenta censeri deberet, invincibilem scilicet vim habitura et ad inveneniendum et ad retinendum et ad dijudicandum". Zob. Jurkowski, Od wieży Babel do języka kosmitów, 20-35.

${ }_{82}$ Zob. Jerzy Kopania, „Stanowisko Descartesa w kwestii języka uniwersalnego”, w: Znaczenie i prawda, red. Jerzy Pelc (Warszawa: Wydawnictwo Naukowe PWN, 1994), 155. 
spełniać jednak pewien warunek - zgodnie z leibnizjańską teorią reprezentacji powinny ów obiekt wyrażaćs

Ten pośredni sposób myślenia o rzeczach, w którym idea rzeczy nie ujawnia się jako przedmiot apercepcji, nazwany został przez Leibniza ślepym myśleniem (caeca cogitatio) ${ }^{84}$. Jest ono podobne do działań przeprowadzanych na dużych liczbach i Leibniz bardzo często odwoływał się do przykładów arytmetycznych obliczeń. Przekonanie, że w istocie każda operacja umysłowa polega na liczeniu, zostało wprawdzie przejęte od Thomasa Hobbesa ${ }^{85}$, ale Leibniz nadał mu zupełnie nowy wymiar. Zakładając, że prowadzące do apercepcji myślenie jest tożsame z pewnego rodzaju rachunkiem, doszedł do wniosku, że zastąpienie działań umysłu na każdym z jego etapów symboliką odwzorowującą te działania pozwoli odtworzyć cały proces poznawczy i ująć go w odpowiedni system reguł. Istnieje bowiem, jak pisał, naturalny porządek idei wspólny aniołom i ludziom, i w ogóle wszystkim inteligencjom ${ }^{86}$. Cały zatem projekt budowy języka uniwersalnego był próbą odtworzenia owego naturalnego porządku.

Leibniz założył, że apercepcja, a więc myślenie prowadzące do idei, ma charakter algorytmiczny (tzn. rachunkowy). Nie wynika stąd, że każde myślenie na poziomie świadomości prowadzi do poznania; trudno też zgodzić się z poglądem, że wszelkie myślenie ma charakter algorytmiczny, choć niewątpliwie taki charakter mają zdaniem Leibniza działania umysłu na poziomie nieświadomości. Języki etniczne jako odwzorowujące porządek naszych odkryć pozwalają odtworzyć wszelkie myśli, które pozostają w zgodzie z wewnętrznym porządkiem idei, ale odzwierciedlają też te działania umysłu, które prowadzą do błędnych sądów i przekonann ${ }^{87}$. Nie są to zatem systemy, które pozwalają odtworzyć rzeczywistą strukturę naszego poznania, choć niewątpliwie umoż-

${ }^{83}$ Zob. Gottfried Wilhelm Leibniz, Quid sit idea, GP VII, 263-264. Zob. też GP VII, 198-201.

${ }^{84}$ Zob. m.in. tenże, Meditationes de cognitione, veritate et ideis, GP IV, 423.

${ }_{85}$ Tenże, De arte combinatoria, GP IV, 64, gdzie Leibniz pisze: „Hobbes merito posuit omne Opus mentis nostrae esse computationem".

${ }^{86}$ Tenże, Nowe rozważania dotyczące rozumu ludzkiego, t. II, s. 11.

87 Zob. tenże, „Rozprawa metafizyczna, XIV”, w: Wyznanie wiary filozofa, 114 oraz tenże, „Podstawy formalizacji rozumowań”, w: Gordon, Leibniz, 251: „ęzyki powszechnie używane obciążone są niezliczonymi wieloznacznościami i nie mogą spełniać zadań rachunku, w którym można by ujawnić błędy rozumowania na podstawie samej formy i struktury słów". 
liwiają wniknięcie w te obszary świadomości, które są werbalizowalne. Oczywiście, wydaje się, że jest możliwa próba przebudowy tych języków, tak by utworzony w jej wyniku system był izomorficzny $\mathrm{z}$ naturalnym porządkiem idei, ale wcześniej jednak należy znać ów porządek. Podjęty przez Leibniza wysiłek przebudowy języka łacińskiego wskazuje, że dostosowanie gotowego systemu językowego nawet do jasnych założeń o strukturze naszego poznania jest zadaniem jeśli nie niewykonalnym, to niesłychanie trudnym w praktycznej realizacji. Należy jednak pamiętać, że wizja języka doskonałego nie przesłoniła Leibnizowi użyteczności poznawczej języków już istniejących. Jego zdaniem każdy język nadaje się do rejestrowania odkryć i każdy - nawet najuboższy - może wyrazić wszystko ${ }^{88}$. Jeśli jeszcze nie jesteśmy w stanie zbudować języka uniwersalnego, należy skupić się na poznaniu i doskonaleniu własnego języka; języki etniczne, jako „najstarsze zabytki ludów”89, pozwalają „odtworzyć historię naszych odkryć" ${ }^{90}$, a postęp w nauce zależy od jasnego i precyzyjnego formułowania myśli ${ }^{91}$.

Założenie o istnieniu naturalnego porządku idei, który jest systemem reprezentacji wewnątrzumysłowej, wynika z jednego z podstawowych założeń leibnizjańskiej metafizyki. Umysł jako monada, zamknięty na wszelkie działania z zewnątrz, cały wszechświat odnajduje w sobie. Naturalny porządek idei jest izomorficzny z porządkiem wszechświata, porządek ten zaś to konsekwencja działań Stwórcy, który wybierając najlepszy z możliwych światów, stworzył go zgodnie $\mathrm{z}$ wewnętrznym porządkiem własnych myśli, bo „gdy Bóg rachuje i snuje myśli, świat się staje" ${ }^{\text {92 }}$. Dla Leibniza, podobnie jak dla wielu innych myślicieli, porządek świata jest porządkiem matematycznym, a sam Bóg jest matematykiem.

Wybitny współczesny matematyk Stanisław Ulam zauważa, że każdy formalizm, każdy algorytm ma w sobie pewien magiczny urok ${ }^{93}$. Zafascynowany pięknem matematyki Leibniz niewątpliwie pozostawał pod urokiem

88 Leibniz, „Analysis linguarum”, C, 352.

89 Tenże, Nowe rozważania dotyczące rozumu ludzkiego, t. II, s. 11.

90 Tamże.

91 GP IV, 138.

92 Gottfried Wilhelm Leibniz, „Dialog o powiązaniu słów i rzeczy oraz o naturze prawdy”, w: tenże, Wyznanie wiary filozofa, 79.

93 Stanisław Ulam, Przygody matematyka (Warszawa: Prószyński i S-ka, 1996), 305. 
procedur algorytmicznych. Filum cogitationis, caeca cogitatio czy calculus to wyrażenia, które bezpośrednio odwołują się do idei algorytmu ${ }^{94}$.

$\mathrm{U}$ podstaw procedur algorytmicznych leży język zdefiniowany w czysto formalny sposób, to jest odwołujący się tylko do fizycznego kształtu wyrażeń i ich połączeń. Niewątpliwie taki właśnie język był ideałem, do którego dążył Leibniz.

Postęp sztuki inwencji rozumowej zależny jest w znacznej mierze od sztuki znakowania. [...] Gdyby utworzono albo jakiś ścisły język (nazwany przez niektórych Adamowym), albo przynajmniej pewnego rodzaju pismo prawdziwie filozoficzne, z pomocą którego pojęcia zostałyby sprowadzone do jakiegoś alfabetu myśli ludzkich, to by wszystko, do czego można dojść rozumem na podstawie danych, dało się uzyskać poprzez pewien swoisty rachunek w ten właśnie sposób, w jaki są rozwiązywane problemy arytmetyki lub geometrii ${ }^{95}$.

Uzyskany w ten sposób system stałby się „pewnym zmysłowym i niejako mechanicznym przewodnikiem umysłu, zrozumiałym nawet dla najgłupszych. Jako że podążanie za tekstem i myślenie będzie przebiegało stopniowo, oznacza to, że pisany tekst będzie wątkiem dla myśli" ${ }^{\circ 6}$.

Co więcej, pozwoliłoby to rozstrzygać o prawdzie w czysto mechaniczny sposób; tak, że „prawda widzialna byłaby jak na obrazku, jakby była wydrukowana przez maszynę. Stałoby się tak dzięki temu, że kryterium, które tworzyłoby prawdę, byłoby ustanowione w sposób mechaniczny, czyniąc ją widzialną" 97 .

Historycy nauki wskazują, że leibnizjański projekt języka uniwersalnego antycypował zarówno program formalizacji języka matematyki ogłoszony w 1900 roku na II Kongresie Matematyki w Paryżu przez Davida Hilberta, jak i współczesny program Sztucznej Inteligencji, ze względu na przekonanie, że każdy twórczy przejaw ludzkiego myślenia jest w istocie rachunkiem ${ }^{98}$.

94 Marciszewski, Murawski, Mechanization of Reasoning in a Historical Perspective, 76.

95 GP VII, 198-199, przeł. Mieczysław Gordon, w: Leibniz, 95.

96 GP VII, 14.

97 GP VII, 10.

98 Zob. Witold Marciszewski, „Why Leibniz should not have believed in filum cogitationis”, w: Leibniz and Europe, VI Internationaler Leibniz Kongreß Vorträge I Teil (Hannover, 1994), 5-17, a także Witold Marciszewski, „From the mechanization of reasoning to a study of 
Dzięki odpowiedniej symbolice można byłoby w każdej dziedzinie - o ile tylko podlegałaby ona rozumowaniu - zrobić wszystko, co można zrobić $\mathrm{w}$ arytmetyce i geometrii.

Obiekt niedościgłych marzeń Leibniza, nowy język wyrażający wszystkie nasze myśli, wprawdzie trudny do zbudowania, ale łatwy do nauki,

z powodu swojego ogromnego pożytku i zdumiewającej łatwości zostanie wnet przyjęty przez wszystkich i cudownie się przyda porozumiewaniu wielu narodów, a to skłoni do jego przyjęcia. Ci, którzy będą pisać w tym języku, nie pomylą się w niczym, o ile unikną błędów rachunkowych, barbaryzmów, solecyzmów i innych omyłek w formach gramatycznych i budowie zdań. Język ten będzie miał ponadto cudowną właściwość: zamknie usta ignorantom. Będzie można bowiem mówić lub pisać w tym języku jedynie na te tematy, jakie się samemu rozumie. [...] Ponieważ rzeczywiście ci, którzy liczą, uczą się pisząc, a ci, którzy mówią, niejednokrotnie napotykają coś, o czym nie myśleli, lingua praecurrante mentem. Co będzie miało miejsce zwłaszcza w tym języku z powodu jego ścisłości. Tym bardziej, że znikną wszystkie ekwiwokacje i amfibolie, a wszystko, co będzie wypowiedziane zrozumiale, będzie powiedziane do rzeczy ${ }^{99}$.

Naturalny porządek idei stanie się osiągalny dzięki symbolice, która odtwarza alfabet ludzkich myśli. Język odnajdzie w ten sposób utraconą przez wieki przezroczystość, pozwalając ujrzeć ideę poprzez jej znak. Będzie tym systemem, który łączy wszystkie języki etniczne, bo wszystkie powinny być redukowalne do tego wspólnego wzorca. Jeśli przyczyną istnienia wszystkich języków jest naturalny system idei, to mimo dzielących ich różnic stanowią one harmonijną całość, wyrażają bowiem tę samą rzeczywistość i odwołują się do tego samego wewnątrzumysłowego porządku myśli. Każdy język ujmuje tę rzeczywistość z innej perspektywy, podobnie jak każda monada postrzega świat $\mathrm{z}$ własnego punktu widzenia. Język doskonały to fizyczna reprezentacja postrzeżeń każdego myślącego umysłu. Jeśli tym, co różnicuje monady, jest perspektywa postrzeżeń, wynika stąd, że tej samej zasadzie podlega system te postrzeżenia ujmujący. W swym wyznaniu wiary w możliwość utworzenia

human intelligence", Studies in Logic, Grammar and Rhetoric XII/XIII (Białystok, 1993/1994): 5-60.

99 Leibniz, „Przedmowa do nauki ogólnej”, 73-74. 
uniwersalnej symboliki zadbał Leibniz o zgodność programu z zasadą indywidualizacji. Język ten bowiem stanowiłby miarę zaawansowania poznawczego jego użytkowników, którą byłby stopień znajomości i sprawności posługiwania się algorytmem. Prowadząc czy wręcz poprzedzając myśl, pozwoliłby uznawać jedynie to, co jawi się jako jasne i co jako takie jest wyrażalne, podobnie jak ma to miejsce w procesie apercepcji.

Poszukiwanie uniwersalnej symboliki jako najpotężniejszego narzędzia rozumu to wielka część europejskiej historii idei, którą stanowi nie tylko chęć wypracowania wspólnego narzędzia porozumiewania się, ale potrzeba dotarcia do zasadniczych wspólnych sensów, które pozwoliłyby przezwyciężyć następstwa budowania wieży Babel. Pierwsze próby znalezienia języka doskonałego to sięgnięcie do hebrajskiej Biblii. Średniowiecze przyjęło sugerowane przez Pismo święte przekonanie o pierwotnym charakterze języka hebrajskiego, które przetrwało jako ugruntowana teologicznie doktryna o pochodzeniu języka aż do XVIII wieku. Dante Alighieri w traktacie De vulgari eloquentia pisał, że język hebrajski „zachował się po zamieszaniu babilońskim, by Jezus, przyszły Zbawiciel świata, mógł mówić językiem łaski, a nie zamieszania"100. Argumentów na rzecz hebrajskiej monogenezy dostarczała też żydowska mistyka. Według kabalistów tekst pisany Tory i Talmudu zawiera zaszyfrowany tekst wiecznej Tory, która istniała jeszcze przed Stworzeniem. Złamanie szyfru będzie więc kluczem do uzyskania ostatecznej mądrości. Leibniz jako jeden z pierwszych zakwestionował prymat języka hebrajskiego jako pierwszego języka ludzkości, wskazując na prajęzyk, który czasami za Jakubem Boehmem nazywał lingua adamica.

Poczucie pewności i piękna, którą niesie ze sobą symbolika matematyczna, stało się źródłem inspiracji dla różnych projektów uniwersalnej notacji, przede wszystkim w obszarze nauk dedukcyjnych. Przełomowy w tym obszarze jest rok 1897, kiedy to niemiecki matematyk Gottlob Frege publikuje pracę zatytułowaną Begriffsschrift, w której wyraźnie wybrzmiewają leibnizjańskie inspiracje. Dzieło to otwiera nową epokę w logice formalnej

100 Zob. Adam Heinz, Dzieje językoznawstwa w zarysie (Warszawa: Państwowe Wydawnictwo Naukowe, 1978), 81. 
i matematyce. Jego bezpośrednią konsekwencją jest wspomniany wcześniej program formalizacji matematyki, ogłoszony przez Hilberta w $1900 \mathrm{roku}^{101}$.

W tym samym czasie potrzebę skonstruowania jednego międzynarodowego języka powszechnego podnosi Louis Couturat, pierwszy wydawca pism logicznych Leibniza, który wraz z Léopoldem Leau przedstawia w pracy zatytułowanej Histoire de la langue universelle, wydanej w 1903 roku $^{102}$, trzydzieści osiem aposteriorycznych i mieszanych systemów językowych powstałych w XIX wieku. Nie istnieje jednak powszechny język doskonały, w którym porozumiewamy się, piszemy poezje i który jednocześnie - jak chciał tego Leibniz - wiedzie nas za pomocą symboliki po ścieżce prawdy. Istnieje jednak matematyka, która jest pewnym zwięzłym sposobem sformalizowania racjonalnego myślenia i okazuje się zadziwiająco skuteczna w wyjaśnianiu tajemnic świata fizycznego. Filozof bardzo wyraźnie wskazywał ten związek, twierdząc, że u podstaw różnorodności zjawisk leżą zasady matematycznego porządku ${ }^{103}$.

\section{Bibliografia}

Aarsleff Hans. 1982. „The History of Linguistics and Professor Chomsky”. W: Hans Aarsleff. From Locke to Saussure. Minneapolis: University of Minnesota Press.

Bacon Francis. 1905. „De Augumentis Scientiarum”. W: Philosophical Works, red. John M. Robertson. London: George Routledge and Sons.

Bacon Francis. 1905. „The Advancement of Learning”. W: Philosophical Works, red. John M. Robertson. London: George Routledge and Sons.

Chomsky Noam. 1966. Cartesian Linguistics. New York: Harper \& Row. Cohen John. 1954. „On the Project of a Universal Character”. Mind LXII.

101 Problematykę tę szczegółowo przedstawia Witold Marciszewski w artykule „Does science progress towards ever higher solvability through feedbacks between insights and routines?", Studia Semiotyczne XXXII, 2 (2018): 155-186.

102 Louis Couturat, Léopold Lean, Histoire de la langue universelle (Paris: Hachette, 1903). Zob. też Umberto Eco, W poszukiwaniu języka uniwersalnego, przeł. Wojciech Soliński (Gdańsk-Warszawa: Wydawnictwo Marabut, 2002).

103 Zob. Paul Davies, Plan stwórcy. Naukowe podstawy racjonalnej wizji świata, przeł. Marek Krośniak (Kraków: Znak, 1996), 165-167. 
Copleston Frederick. 1995. Historia filozofii. T. IV, przeł. Józef Marzęcki. Warszawa: Instytut Wydawniczy PAX.

Correia Manuel Antonio. 1994. „De Arte combinatoria: Unity and Harmony in the Doctrine of the Whole and Parts". In: Leibniz and Europa. VI Internationales Leibniz Kongress Vorträge I Teil. Hannover.

Couturat Louis, Léopold Leau. 1903. Histoire de la langue universelle. Paris: Hachette. Couturat Louis. 1901. La Logique de Leibniz. Paris: Hachette.

Czeżowski Tadeusz. 1969. Odczyty filozoficzne. Toruń: Państwowe Wydawnictwo Naukowe.

Dascal Marcelo. 1990. „Leibniz on Particle”. W: Leibniz, Humboldt, and the Origins of Comparativism, red. Tullio de Mauro, Lia Formigari. Amsterdam-Philadelphia: John Benjamins Publishing.

Davies Paul. 1996. Plan stwórcy. Naukowe podstawy racjonalnej wizji świata, przeł. Marek Krośniak. Kraków: Znak.

Descartes René. 1974-1983. Oeuvres de Descartes. T. I. Publiées par Ch. Adam, Paul Tannery, 76-82. Paris [cytowane jako AT].

Eco Umberto. 2002. W poszukiwaniu języka uniwersalnego, przeł. Wojciech Soliński. Gdańsk-Warszawa: Wydawnictwo Marabut.

Gordon Mieczysław. 1973. Leibniz. Warszawa: Wiedza Powszechna.

Guiraud Pierre. 1972. La Sémantique. Wyd. 7. Paris.

Heinz Adam. 1978. Dzieje językoznawstwa w zarysie. Warszawa: Państwowe Wydawnictwo Naukowe.

Jurkowski Marian. 1986. Od wieży Babel do języka kosmitów. Białystok: Krajowa Agencja Wydawnicza.

Kopania Jerzy. 1988. Funkcje poznawcze Descartesa teorii idei. Białystok: Dział Wydawnictw Filii UW.

Kopania Jerzy. 1994. „Stanowisko Descartesa w kwestii języka uniwersalnego”. W: Znaczenie i prawda, red. Jerzy Pelc. Warszawa: Wydawnictwo Naukowe PWN.

Leibniz Gottfried Wilhelm. 1849-1853. Dissertatio de arte combinatoria in qua ex arithmeticae fundamentis complicationum ac transpositionum doctrina novis praeceptis extruitur, et usus ambarum per universum scientiarum orbem ostenditur; nowa etiam ars meditandi seu logicae inventionis semina spargantur. W: Gottfried Wilhelm Leibniz, Die Philosophischen Schriften von G. W. Leibniz. T. VII, red. C. I. Gerhard (repr. Hildesheim 1960). T. IV, 64-65 [cytowane jako GP, tom, strona].

Leibniz Gottfried Wilhelm. 1767. Gothofiedi Guiliemi Leibnitii Opera Omnia, nunc primum par colleta... par Ludovitius Dudens. Vol. VI. Genève. 
Leibniz Gottfried Wilhelm. 1849-1853. Die Philosophischen Schriften von G. W. Leibniz. T. VII, red. C. I. Gerhard (repr. Hildesheim 1960) [cytowane jako GP, tom, strona].

Leibniz Gottfried Wilhelm. 1849-1853. Die Philosophischen Schriften von G. W. Leibniz. T. VII, red. C. I. Gerhard (repr. Hildesheim 1960). T. IV, 64-65 [cytowane jako GP, tom, strona].

Leibniz Gottfried Wilhelm. 1903. Opuscules et Fragments Inédits, extraits des manuscrits de la biblithéque royale de Hanovre par Louis Couturat. Paris (repr. Hildesheim 1962), 352 [cytowane jako C].

Leibniz Gottfried Wilhelm. 1955. Nowe rozważania dotyczace rozumu ludzkiego, przeł. Izydora Dąmbska. Warszawa: Państwowe Wydawnictwo Naukowe.

Leibniz Gottfried Wilhelm. 1969. Wyznanie wiary filozofa, przeł. Stanisław Cichowicz. Warszawa: Państwowe Wydawnictwo Naukowe.

Leibniz Gottfried Wilhelm. 1982. Allgemeine Untersuchungen über die Analyse der Begriffe und Wahrheiten. Hamburg: Felix Meiner Verlag.

Lyons John. 1975. Wstęp do językoznawstwa, przeł. Krzysztof Bogacki. Warszawa: Państwowe Wydawnictwo Naukowe.

Marciszewski Witold, Roman Murawski. 1995. Mechanization of Reasoning in a Historical Perspective. Amsterdam-Atlanta: Brill Rodopi.

Marciszewski Witold. 1993/1994. „From the mechanization of reasoning to a study of human intelligence", Studies in Logic, Grammar and Rhetoric XII/XIII. Białystok.

Marciszewski Witold. 1994. "Why Leibniz should not have believed in filum cogitationis". W: Leibniz und Europa, VI Internationaler Leibniz Kongreß Vorträge I Teil, 5-17. Hannover.

Marciszewski Witold. 2018. „Does science progress towards ever higher solvability through feedbacks between insights and routines?". Studia Semiotyczne XXXII (2): 155-186.

Mates Benson. 1986. The philosophy of Leibniz. 178-183. Oxford: Oxford University Press.

MacDonald Ross G. 1984. Leibniz. Oxford: Oxford University Press.

McRae Robert. 1988. „Locke and Leibniz on Linguistic Particles”. Synthese 75 (2).

Merkel Franz Rudolf. 1952. Leibniz und China. W: Leibniz zu seinem 300. Geburtstag. Berlin: W. De Gruyter.

Święczkowska Halina. 2008. Język jako projekt polityczny. Kraków: Wydawnictwo Aureus.

Święczkowska Halina. 2016. Language as the mirror of world order. Białystok: Uniwersytet w Białymstoku.

Ulam Stanisław. 1996. Przygody matematyka. Warszawa: Prószyński i S-ka.

Walker D. P. 1972. „Leibniz and Language”. Journal of the Warburg and Courtauld Institutes 35. 
Ward S. 1654. Vindiciae Academiarum. Oxford.

Wierzbicka Anna. 1975. „W poszukiwaniu tradycji. Idee semantyczne Leibniza”. Pamiętnik Literacki LXVI: 109-126.

\section{Abstract \\ Leibnizian Idea of a Universal Language}

Gottfried Wilhelm Leibniz, the creator of one of the largest modern philosophical systems, deserves our attention as a theoretician of the language for several reasons. Firstly, due to the cognitive issue of the function of the language sign studies by the philosopher, as well as the role of the sign in the thought process. The Leibnizian theory of cognition rests, to a large extent, on a linguistic foundation. Secondly, Leibniz is a representative of the material linguistics, author of many studies and dissertations, in which he deals with the origin of language and genealogical classification of world languages. By emphasizing the culture-forming nature of language, the philosopher investigated the functions of language in the life of an individual and society. For the most part, Leibniz is recognized as one of the originators of the idea of a universal language, an idea that accompanied him since the very inception of his scientific pursuits. Undoubtedly, this idea stood in close relation to the philosophical system the philosopher was building. It can be assumed that the successive Leibnizian projects that were aimed at the implementation of the above idea resulted also from the intensive research on existing language systems conceived of by the philosopher in a very broad sense. Paradoxically, though Leibniz has been associated with the idea of a perfect language, he never went beyond his preliminary sketches and tentative comments on this project. It is worth, then, inquiring into the reasons justifying the need for creating such a language and the goals that the thinker would like to achieve with it. This essay is an attempt to offer at least a partial answer to the question concerning Leibniz's motivation for the need to create a universal language. It is relevant, among other things, due to Leibniz's claim which contradicts the idea of a universal language, in which he clearly stresses that "every language, even the poorest one, can express everything", as well as owing to Leibniz's historical contribution to the idea of formalization and to the mechanization of the reasoning processes. This paper is also an attempt to reconstruct the paradigm of language research pursued in a specific period of time in $17^{\text {th }}$ century language theory.

Keywords: philosophy of language, Leibniz, universal language. 


\section{Streszczenie}

\section{Leibnizjańska idea języka uniwersalnego}

Gottfried Wilhelm Leibniz, twórca jednego z największych nowożytnych systemów filozoficznych, zasługuje na uwagę jako teoretyk języka z co najmniej kilku powodów. Po pierwsze ze względu na podjęcie przezeń kwestii poznawczej funkcji znaku językowego i jego roli w procesie myślowym. Leibnizjańska teoria poznania zbudowana jest w znacznej mierze na językowym fundamencie. Po drugie jest Leibniz przedstawicielem nurtu językoznawstwa materiałowego, autorem wielu studiów i rozpraw, w których podejmuje problematykę pochodzenia języka i klasyfikacji genealogicznej języków świata, prowadzi także badania na temat funkcji języka w życiu jednostki i społeczeństwa, podkreślając jego kulturotwórczy charakter. Po trzecie wreszcie jest Leibniz rozpoznawany najczęściej jako jeden z pomysłodawców idei języka uniwersalnego, która towarzyszyła mu od początku jego drogi naukowej. Idea ta pozostawała niewątpliwie w ścisłym związku z budowanym przezeń systemem filozoficznym. Można przypuszczać, że kolejne projekty Leibniza, zmierzające do jej urzeczywistnienia, wynikały również z intensywnych badań nad istniejącymi już systemami językowymi w bardzo szerokim ich rozumieniu. Paradoksalnie jednak, choć identyfikowany z ideą języka doskonałego, Leibniz nie wyszedł nigdy poza wstępne szkice i komentarze dotyczące tego projektu. Warto zatem prześledzić racje uzasadniające potrzebę utworzenia takiego języka i cele, które za jego pomocą chciał osiągnąć. Esej ten jest próbą udzielenia przynajmniej częściowej odpowiedzi na pytanie o motywację Leibniza na rzecz potrzeby języka uniwersalnego. Jest ono zasadne między innymi ze względu na stojącą w sprzeczności z ideą języka uniwersalnego jedną z wypowiedzi Leibniza, w której wyraźnie podkreśla on, że „każdy język, nawet najuboższy, może wyrażać wszystko”, jak również z uwagi na historyczny wkład Leibniza w ideę formalizacji i mechanizacji procesów rozumowań. Jest to również próba rekonstrukcji paradygmatu badań językowych, obowiązującego w pewnym obszarze siedemnastowiecznej teorii języka.

Słowa kluczowe: filozofia języka, Leibniz, język uniwersalny. 